\section{Entrepreneurial Women in Brazil: What Are Their Fears?}

\author{
Raquel Adriano Momm Maciel de Camargo \\ Federal University of Paraná, Department of Administration, Curitiba, PR, Brazil \\ Mariane Lemos Lourenço \\ Federal University of Paraná, Department of Administration, Curitiba, PR, Brazil
}

Jane Mendes Ferreira

Federal University of Paraná, Department of Administration, Curitiba, PR, Brazil
Received on

11/07/2016

Approved on

$10 / 03 / 2017$

Responsible editor:

Prof. Dr. J. Ignacio Canales

Evaluation process:

Double Blind Review

\begin{abstract}
Purpose - This article aims to investigate the fears of entrepreneurial women in consolidated businesses, in view of the current volatile political and economic situation in Brazil.
\end{abstract}

Design/methodology/approach - We chose a qualitative and interpretative approach, using in-depth interviews with expert entrepreneurs with already consolidated businesses as the data collection technique. We did not define the categories a priori, but instead they emerged inductively from what the interviewees said.

Findings - The findings indicate that the fears present in entrepreneurial activities go beyond those related to opening a business and its continuity, such as fear of bankruptcy. We noticed that during the entrepreneurial trajectory, fears alter and can be grouped into the following categories: fears related to the future of the enterprise and the entrepreneur; specific fears concerning the business sector; fears related to financial aspects. The economic instability in Brazil seems to be an aggravating factor and was present at all times in the women's statements.

Originality/value - The theoretical contribution of this study lies in the finding that there are fears that can change as the woman and the enterprise mature. This finding goes beyond the fears commonly found in the literature, which are the fear of opening a new business and that of failure or bankruptcy. This study is aligned with those that address the emotions that permeate entrepreneurial activities. By identifying that women have different types of fears over time, the study could, as a practical contribution, lead to business training programs that, in addition to technical aspects, also include emotional dimensions to better prepare entrepreneurial women.

Keywords - Entrepreneurial women; fear; emotions; Brazil.

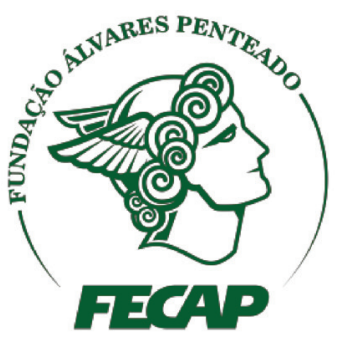

\section{Review of Business Management}

DOI: $10.7819 /$ rbgn.v20i2.3578 


\section{Introduction}

Since McClelland (1971, 1987), the desirable characteristics of an entrepreneur have been at the core of studies on individuals who carry out entrepreneurial activities. In an environment where risk propensity and heroic attitudes are emphasized, fear has become a forgotten dimension in most research on entrepreneurship, especially when it comes to women. However, other dimensions of life, history, and emotions can provide important contributions to understanding how an individual becomes an entrepreneur. In this article, fear is the central theme. For Cacciotti and Hayton (2015), fear of bankruptcy and failure are the most present forms in the literature on entrepreneurship, followed by fear of opening a new business. This study is thus warranted as it presents an innovative perspective on understanding fear as part of the entrepreneurial journey, moving away from the idea of "fearless heroes", so that the narrative on entrepreneurship can be addressed more realistically. To ignore the fears that permeate the activity by restricting them to the beginning (fear of opening) or the potential end (fear of bankruptcy) is to ignore that there is any kind of emotion between these two poles.

Therefore, this article addresses the suggestion made in research that indicates the relevance of studying the emotions of entrepreneurs and the complex context in which they perform (Welpe et al., 2012; Cacciotti \& Hayton, 2015). Cacciotti et al. (2016) revealed the need to treat these emotions in a broader social context and as part of the entrepreneurial process. According to Cacciotti and Hayton (2015), fear is an emotion that can be present at all times in the process of opening a business, whether this involves beginner entrepreneurs or experienced entrepreneurs. As evidence of the importance of the topic, Cardon et al. (2012) presented an edition of Entrepreneurship Theory and Practice especially dedicated to emotions, titled "Exploring the Heart: Entrepreneurial Emotion is a Hot Topic", and they suggest further research on emotions in what is considered the "extreme context that is to open a business venture".

Given the contextualization, this article aims to investigate the fears of entrepreneurial women in consolidated businesses, in view of the current situation of political and economic instability in Brazil. To achieve the proposed objective, we conducted qualitative research of an interpretative nature, using in-depth interviews with expert entrepreneurs with consolidated businesses as the data collection technique. We did not define the categories a priori, but instead they emerged inductively from what the respondents said, revealing the following results: fears concerning the future of the business and of the entrepreneur; specific fears involving the business sector; fears related to financial aspects. The economic instability of Brazil seems to be an aggravating factor and was present the whole time in the statements of the women interviewed.

As a theoretical contribution, this study provides more knowledge on the fears of entrepreneurial women, which develop over the course of their entrepreneurial trajectory at moments of economic, social, and political crises. In terms of practical contributions, the study could lead to policies and entrepreneurial educational programs that acknowledge the importance of working beyond technical aspects and include the emotional dimensions that accompany the trajectory of Brazilian entrepreneurs. To facilitate the reader's understanding of this academic production, in addition to this introduction, we present the theoretical framework of reference that supports this research, the methodological procedures, and the conclusions and contributions that the study can offer to academia and entrepreneurial development projects.

\section{Theoretical Framework}

In a search for the keyword "fear" in the Scientific Electronic Library Online (Scielo), we found 2,195 studies that belong to different areas 
of knowledge. However, when the search was combined with the word "entrepreneur", only five papers appeared. An analysis of the studies from the combined search enables us to affirm that fear of starting a business was the focus of those studies, showing that there is still room for fear to be covered more thoroughly, especially with regard to entrepreneurial activities. In this section we shall briefly discuss the concept of fear as an emotion and the literature that relates fear and entrepreneurship, and then we will present studies that specifically contemplate entrepreneurship and entrepreneurial women.

\section{I Fear and entrepreneurship}

To work on the concept of fear, it is necessary to acknowledge that fear can be understood from different perspectives and in relation to different periods. Throughout the whole of history, people have learned to have specific fears, they have developed new fears, and they have taught them to others. Fear is immutable and takes different forms (Santos, 2003). The reactions that are considered characteristic of fear can be very different, such as flight, retraction, negation, precaution, inhibition, and other feelings with more complex emotional configurations. There are also other emotions, such as anguish, terror, fright, and dread, which although similar in some respects, cannot be defined as fear. With so many distinctions, it is not a simple task to conceptualize what fear is (Pagès et al., 1987; Santos, 2003) and this becomes even more complex when it is understood in conjunction with entrepreneurial activity.

Pagès et al. (1987) consider a distinction psychology makes between fear and anguish. Fear is limited in time and space and has a specific object, whilst anguish is more comprehensive and diffuse, and is present all the time and able to be everywhere and in various objects (Pagés et al., 1987). For Elias (1994), the origin of many people's fears today lies in the conflicts that originate from constantly questioning the relationship between the individual and society and these conflicts consequently provoke agitation and fear in the people involved. Thus, the fear derived from the conflicts between the individual and society can be shared by a particular group, such as the entrepreneurs of a particular productive sector, or even of an entire country experiencing the same crisis. It can therefore be stated that some of the fears that emerge among people involved in entrepreneurial activities can be described, because in many ways the relations between the individual and society are similar. When they work in the same sector or are in the same context of financial or political instability, entrepreneurs develop similar fears. Research that relates fear and entrepreneurship in particular will be presented below.

The presence of fear is a complex issue that has scarcely been studied in relation to the experience of opening a business; in other words, fear is the least-told part of the entrepreneur's life story. In addition, existing studies indicate the need for conceptual accuracy and a deepening of the understanding of what fear is when contextualized in entrepreneurship (Cacciotti \& Hayton, 2015).

Fear is an emotion that is experienced by entrepreneurs and is a very important source of research, but it has barely been discussed by researchers of the subject, as well as other emotions such as frustration (Gimenez, 2013). This position is in line with that presented by Welpe et al. (2012), for whom the value of emotions in entrepreneurial actions has not been studied consistently. Welpe et al. (2012) investigated the effects of emotions such as fear, joy, and anger on entrepreneurial activity and argue that entrepreneurs should know that their perception of opportunity is always subjective, and that their emotions directly affect their decisions, as well as their ability to assess and tap into new opportunities. The work of these authors indicates that emotions such as joy and anger have a positive effect on evaluations and on exploring opportunities, but it indicates fear as a typically negative emotion, from the fact that the greater 
the fear level of an entrepreneur, the lower his or her tendency is to evaluate and tap into a new opportunity.

Cacciotti and Hayton (2015) carried out a literature review of empirical articles that related fear and entrepreneurship and found 44 that related the two themes. Their findings show that fear has been predominantly researched in relation to bankruptcy and failure, followed by fear as a barrier to starting entrepreneurial activity. Among the articles cited, many study the relationship between fear and entrepreneurship, especially as an emotion that negatively impacts opening a new business.

Within this context, in a survey of entrepreneurs carried out in Tunisia, Kefacha, Belkacem, \& Mansouri (2013) concluded that fear negatively influenced the decision to start a business. Wagner (2007) researched the differences between men and women in their decision to start a new business in Germany, and noted fear of bankruptcy as something that could hinder both men and women in starting a business venture. Anokhin and Abarca (2011) demonstrated that human agency is a filter that affects the perception of objective opportunities; and the great fear of failure prevents the perception of opportunities to start a new business. In a survey that included 127 regions and 17 European countries, Bosma and Schujtens (2011) concluded that fear of failure when opening a new business is, among other factors, one of the components that affects entrepreneurial attitude. When analyzing 24 GEM participating countries, Hessels et al. (2011) also mention resistance to opening a new business related to fear of failure, but they indicated that fear of failure may vary from country to country. Wood and Pearson (2009) also considered the effects of fear and individual differences related to self-efficacy and found that lack of support for the individual related to individual differences played a significant role in the decision to open a new business. The studies carried out by Morgan and Sisak (2016) state that fear of failure is strongly associated with context and is always negative in the decision to start a new business. Qian and Miao (2016) report that cultural factors, such as the case of countries that encourage entrepreneurship, can alleviate the fears expressed by entrepreneurs.

In a recent study, Cacciotti et al. (2016) conducted qualitative and exploratory research with the purpose of interpreting fear of failure from the perspective of the entrepreneurs themselves. They point to fear of failure in entrepreneurship as a temporary emotional experience that can affect decisions, actions, and activities over the course of the entrepreneurial trajectory. In their study, the authors identified seven different sources of fear in entrepreneurship: financial security, personal capacity, ability to finance the business venture, potential of the idea, social esteem, ability to execute, and opportunity costs. For these authors, fear of failure is understood together with their affective, cognitive, and behavioral responses, and is present in the course of the entrepreneurial process. In addition to the impacts of economic crises, the entrepreneurs in one sector share specific aspects of its context, such as changes in regulation, so that they also share fears related to acting in that same particular context (Caccioti et al.,2016).

The research by Mota et al. (2017) also contemplated entrepreneurship within an economic and social context and concluded that indicators such as GDP, income per capita, and Human Development Index can negatively affect the perception of opportunities for entrepreneurship within a given country, at the same time as increasing entrepreneurs' fear of failing in their business ventures. To help understand the fears related to the entrepreneurial trajectory of women, we will next present the issues that involve entrepreneurship and entrepreneurial women.

\subsection{Entrepreneurial Women}

The performance of women in entrepreneurial activity has increased and consolidated in recent years in Brazil (Ferreira 
\& Nogueira, 2013). This can be verified by comparing the 2005 and 2015 data of the Global Entrepreneurship Monitor. In 2005, Brazil already appeared to enjoy a favorable position in female entrepreneurship. In proportional numbers, while $11.8 \%$ of men were entrepreneurial in Brazil, $10.8 \%$ of women were already in entrepreneurial activities, occupying 6th place in the world. In absolute numbers, Brazilians ranked third in terms of female entrepreneurship in 2005, just after the Americans and the Chinese, countries with substantially larger populations than that of Brazil. Ten years later, in addition to entrepreneurship growth, GEM 2015 presented one of the most outstanding characteristics of Brazilian entrepreneurship: gender equality, with an initial male entrepreneurship rate of $21.70 \%$ and female entrepreneurship rate of $20.30 \%$. These percentages keep Brazil in a position of prominence in relation to the other countries analyzed with regard to the participation of women in entrepreneurial activity. According to GEM 2015, the United States featured 9.2\% of women and $14.6 \%$ of men in early-stage entrepreneurship, in China this was $10.3 \%$ of women and $15.3 \%$ of men, and in Germany it was $3.3 \%$ of women and $6.1 \%$ of men. But while in 2005 the percentage of women in the early-stage of a business venture was already close to the percentage of entrepreneurial men, the percentage of women who were at the forefront of consolidated businesses showed that there was still a lot of work ahead. GEM 2005 indicated that for every woman who was at the head of a consolidated business, there were two men leading a business. The GEM data from ten years later showed that $21.30 \%$ of entrepreneurial men and $16.60 \%$ of entrepreneurial women were at the head of businesses that survived the first three and a half years. There was a significant increase in the presence of women: 1.2 men for every woman who ran a consolidated business (GEM, 2015). These data show the expansion and consolidation of the presence of women in entrepreneurial activity. As well as the expansion of the performance of entrepreneurial women in Brazil, there has also been an increase in research on female entrepreneurship in national studies.

Whereas in the international literature studies on female entrepreneurship emerged in the mid-1970s and grew significantly in the 1980s (Gomes et al., 2014), in Brazil they have only started to appear three decades after the first articles on the subject were published in journals. The data are presented by Gimenez, Ferreira, and Ramos (2017), who studied the emergence of the field of study in Brazil, and mapped 56 published articles on female entrepreneurship, with the first two being from the year 2000. A qualitative analysis of the scientific production in Brazil carried out with relation to female entrepreneurship shows that motivations are studied, as are perceptions about the role of entrepreneurs in society and the difficulties involved in playing this role, whether in terms of personal, organizational, or social aspects (Gimenez, Ferreira, \& Ramos, 2017). However, "there is still little knowledge about the performance of entrepreneurs in the country" (Machado, Greatti, \& Jesus, 2010, p. 88). Despite the evident relevance of female participation in entrepreneurship, starting a business venture is not an easy task for women, because of greater obstacles to accessing sources of funding, discrimination in inheritance proceedings in family businesses, or other nuances that surround the theme and lack studies (Ferreira \& Nogueira, 2013; Gimenez et al.,2017).

Some studies, such as those by Noguera, Alvares, and Urbano (2013), Wagner (2007), Koellinger et al. (2013), and Minniti and Nardone (2007), address differences between men and women and the fear of failure, but do not provide a more detailed explanation of the differences in the participants' level of entrepreneurship. Gomes et al. (2014) points out that some aspects of female entrepreneurship, such as the form of management or financing, are usually studied in a comparative way between men and women. Arroyo, Fuentes, and Jiménez (2016) 
indicate the importance of the gender perspective when studying entrepreneurship. And for these authors, to advance research on entrepreneurship from the gender perspective, it is necessary to understand the personal and intrinsic factors together with the context. It is worth emphasizing that this study is not about fear of bankruptcy or about making comparisons between men and women. Therefore, important contributions can be made to the understanding of what it is to be an entrepreneurial woman if we perceive her as an individual who constitutes her identity through her interactions with the different areas of life and spheres where she acts, and who seeks to play a social role for which the script has already been defined in terms of what it is to be a male or female entrepreneur (Strauss, 1999; Goffman, 2014, 2015). Being a woman and being a female entrepreneur are socially configured productions that have unique meanings that are attributed by the individuals themselves, giving a unique meaning to their experiences (Ferreira \& Nogueira, 2013).

This understanding is also contextualized by Brazil's political and economic crisis, since the fears that accompany the trajectory of the entrepreneurial woman are not understood separately, but learned and shared within a given social and historical context (Cardon, et. al., 2012; Ferreira \& Nogueira, 2013; Gimenez, 2013; Cacciotti \& Hayton, 2015). When we begin to detail the methodological procedures that guided the development of this research, we will allocate space to presenting the political and economic context of the country during the development of the empirical research.

\section{Methodological Procedures}

We conducted this qualitative and interpretative study in the field, using a crosssection, but also a longitudinal analysis of the entrepreneurial trajectory. The research strategy used is the basic qualitative study described by Merriam (1998, 2002) and Godoy (2005). The basic qualitative study has the characteristics of qualitative research, but does not fit all the criteria that define a case study. Its main characteristics are the researcher's interest in the meaning that respondents give to the reported facts, the researcher is a direct data collection instrument, and the research is inductive in character.

\section{I Research Context}

During the period of this research, Brazil faced one of the greatest political and economic crises in its history. The current recession was already at its worst, with it being said that "nothing similar has been seen since 1990" (Patu \& Bôas, 2016). According to the Central Bank's Consolidated Economic Indicators, Gross Domestic Product (GDP) had been negative for three consecutive years: -0.4 in 2014, -4.6 in 2015, and -4.4 in 2016; the basic interest rate was around 14.5\% (Folha de São Paulo, 2016); average interest rates on credit cards in the country had reached 419.6\% per year, the highest level since October 1995; and the interest on bank overdrafts had reached $255.94 \%$ per year, the highest level since July 1999 (Folha de São Paulo, 2016).

The numbers from the Brazilian economy showed increases in interest rates, declining GDP, the dollar hitting a high, and low growth of industries. In a chaotic scenario, Brazil still suffered from the worst economic indices in its recent history:

\footnotetext{
Brazilian income per capita, measured in PPP (Purchasing Power Parity), reached $38 \%$ of the United States in 1980. But this percentage was not sustained in the following decades: in 2015, the ratio was $28 \%$, according to the International Monetary Fund, which estimates that the living standards of Brazilians will remain stationary at least until 2020" (Fraga, 2016).
}

The political scenario in Brazil was also devastating. Corruption scandals spread across all levels of government, President Dilma Rousseff underwent an impeachment process, and the government of the new president, Michel Temer, was involved in problems that are still 
ongoing. In March 2016, millions of Brazilians took to the streets to show their discontent with the government of President Rousseff and her political party. "Now the crisis deepens in a rare combination of paralysis in government and congress, corruption scandals, unemployment and rising inflation, and generalized uncertainty among entrepreneurs and consumers" (Patu \& Bôas, 2016).

The context is thus presented to investigate the issue of fear in entrepreneurial women in Brazil locally and temporally, taking into account that these aspects can change over time. Who are the entrepreneurs who were interviewed, what were their fears, and what procedures were used to access this knowledge? This information is detailed below.

\subsection{Research Participants}

The participants were intentionally chosen, in accordance with the literature (Merriam, 2009; Creswell, 2010), seeking the internal coherence required of qualitative research in order to select participants that can best help address the scope of the research. In order to achieve the objective of this study, we sought experienced entrepreneurs who were owners of self-sufficient businesses that were their main source of income, who had technical or administrative experience prior to setting up their businesses, and were responsible for or participants in founding the companies they manage, as well as any expansions, innovations, or the creation of new units. They can be considered expert entrepreneurs, due to them operating in highly competitive sectors for at least ten years (Ramos, 2015). According to the literature cited in the theoretical framework, it would be expected that beginner entrepreneurs are afraid of their business. The focus of this study is to understand the existence of fear during the entrepreneurial trajectory and not just in the initial phase. The number of interviews was not defined a priori and we ended the data collection stage when we encountered theoretical saturation, i.e., the new data did not add any new categories to the exploratory research on the subject, i.e., the categories began to repeat. Table 1 gives an overview of the profile of participants.

Table 1

\section{Profile of Participants}

\begin{tabular}{lcccc}
\hline Identification & Age & Experience & Education & Sector \\
\hline Entrepreneur 1 & 53 years & 20 years & Post graduate & Child Education \\
Entrepreneur 2 & 42 years & 20 years & Higher education completed & Child Education \\
Entrepreneur 3 & 53 years & 28 years & Post graduate & Elementary Education \\
Entrepreneur 4 & 40 years & 22 years & High School & Confection/Clothing \\
Entrepreneur 5 & 36 years & 19 years & Post graduate & Ontological clinic \\
Entrepreneur 6 & 49 years & 14 years & Higher education completed & Manipulation Pharmacy \\
\hline
\end{tabular}

Source: Primary Data.

\subsection{Data Collection Technique}

We chose semi-structured interviews as the technique for collecting data (Godoy, 2012); the first semi-structured interview script, also known as the pre-test, underwent any improvements that were necessary. In the interview script, the sequence of topics covered was not rigid, with changes occurring during the interviews in order to stimulate the line of thought that was being presented by the participants (Godoy, 2012). Whenever necessary, the questions were repeated, even if the participant had already partially answered them during another question, ensuring a better vicarious experience of the phenomena studied.

In the elaboration of the interview script, we valued questions that asked "how" over 
questions that asked "why". According to Becker (1999; 2007), researching "how" rather than "why" is an interesting technique for developing qualitative research because it encourages people to report what the experience was like, instead of asking them to explain themselves in their responses. The addition of this knowledge to the research process was very useful, as whenever questions were asked under this format, longer and more elaborate answers were obtained, which provided greater assistance in the search for answers to the proposed objective.

The initial contact in the field took place in a meeting between entrepreneurs, where we obtained permission to explain the purpose of the research and requested the collaboration of entrepreneurs for this study. The date and time of the interviews were previously arranged by phone, according to the availability of the interviewees. All interviews were conducted in person and in all cases the participants defined their own organizations as the place for the interviews. Each of the interviewees was asked if they would authorize the recording; and as soon as we started it, the question was repeated, so that the consent was registered in the recording. The interviews lasted from approximately fifty minutes to an hour. In addition to the authorization to record interviews, we adopted other ethical procedures, such as not mentioning the names of the interviewees, the names of their businesses, names of other people or companies mentioned during the interviews, and other elements that could enable the identification of the participants, ensuring, in addition to the secrecy, that no information revealed in the interviews could expose the participants or third parties.

\subsection{Data analysis}

For a detailed data analysis we used content analysis, based on the steps defined by Strauss and Corbin (2008), showing this data analysis technique to be useful in identifying the main categories of analysis from what the interviewees said. In the analysis, these categories that were not defined a priori but instead were compared to the main aspects addressed in the literature, with the prospect of focusing on the entrepreneurial trajectory, in addition to the aforementioned fears of opening a new business and fear of failure and/or bankruptcy. Fears were thus grouped into categories that emerged from what the interviewees said: fears left in the past; fears about the future of the business venture and the entrepreneur; specific fears concerning the business sector; and fears relating to financial aspects. The interviews were conducted between June 2015 and April 2016 in Curitiba, therefore at the same location and during the same period that investigations took place related to corruption in different spheres of government. The sections from the interviews were designated by a number that refers to the chronology of interviews. The results and analyses of this study are presented below.

\section{Results and Analysis}

From the content of the interviews, different categories associated with fear emerged, which are more than the fear of opening a new business (Welpe et al. 2012) and fear of bankruptcy already contemplated in the literature (Cacciotti \& Hayton, 2015). In the final stage of analysis the categories were grouped into four major themes, as already described in the methodological procedures: fears left in the past; fears about the future; specific fears concerning the business sectors; and fears relating to financial aspects.

\section{I Fears left in the past}

In their study, Cacciotti and Hayton (2015) showed that a lot of research has been dedicated to analyzing the relationship between fear and entrepreneurship, notably as an emotion that negatively affects entrepreneurs when opening a business venture. This was also shown in the studies carried out by Kefacha, Belkacem, \& Mansouri (2013), Wagner (2007), Anokhin and Abarca (2011), Bosma and Schujtens (2011), 
Hessels et al. (2011), Wood and Pearson (2009), Qian \& Miao (2016), and Morgan \& Sisak (2016). The relationship was also confirmed in this study in the statements by the Brazilian entrepreneurs interviewed, who also reported the fears they had at the time of opening their businesses, reporting fears about their capacity to manage a business of their own, splitting their time between their personal and professional lives, and managing without the monthly wage they received as employees:

You can no longer count on a fixed salary, this is the biggest insecurity... greatest challenge, my biggest fear is this, I need to be really economically stable, with my foot on the ground so I can invest in my business. (...). This is a challenge that makes me fear in the beginning a little, but then you start to understand how it works. (Entrepreneur 5)

Fear of opening a new business is not the only one that is left in the past. From the what the interviewees said we can observe that some of the entrepreneurs' fears are located in a specific period of time and are subsequently overcome and replaced by others, so that the fear emotion remains present, while the object of fear changes over the course of the time of the business venture. The following statement shows this:

\begin{abstract}
My first fear was really whether it would work, whether I would find customers, if I would please my clients, if it would work out. And today as time goes by the fears are changing, then you really see that you are able to find customers, deliver service to customers, but the financial instability... (Entrepreneur 4)
\end{abstract}

Brazilian entrepreneurs have also addressed fears that are little discussed in entrepreneurship research and that relate to the future, as will be discussed below.

\subsection{Fears about the future}

Cacciotti et al. (2016) indicate that the literature on the subject is dominated by the fear of failure dimension only in terms of it being a barrier to entering into entrepreneurship, but fear of failure should be studied within a broader social context and also as part of the entrepreneurial process, and not just when opening a business. Thus, with the objective of studying fear within a broader social context and as part of the entrepreneurial process, this research addressed fears related to the whole entrepreneurial trajectory, including fears about the future. The strong bond that the entrepreneurs appeared to have with their business ventures revealed: fears about the future that are intertwined with the financial aspect; fears related to the enterprise in the absence of the entrepreneur; fears related to the future of the entrepreneur if the enterprise becomes unsustainable and she is unable to reenter the labor market. The following testimonies reveal this:

So this fear of the future of the country today is the greatest fear of all, the fear of what could come from this... the fear of insecurity... violence... of the economy as a whole, being as it is I think that no fear is greater than that of the business ceasing to exist... this thing could die out, that's the great fear, and then I might not find a replacement... my husband going through hardship, how will the people who depend on me go on? Then everything stops... this thing stops... I believe it will not stop, we must hope too, otherwise how will this work out? (Entrepreneur 5)

I fear whether the company will have a future, because it is a family business, the fear is that it will end as a result of the owners' death (Entrepreneur 2).

We were also able to outline the way that entrepreneurial women perceive the future of their business ventures based on their fears, as being the fear of not being able to perceive that the company is no longer sustainable due to the strong bond they have with it, expressed in the following testimony:

We are seeking a financial reward, we cannot let this personal bond (with the company) overcome a rational situation. Sometimes (there are entrepreneurs who) 
keep insisting on something that is not working. The business venture is here to make a future dream come true. I see a lot of people getting lost in the middle of the way. People go bankrupt because the owner cannot develop this perception... (Entrepreneur 6)

This fear seems to be little shared and even denied. It is as if in admitting that one day the business could go bankrupt the entrepreneur was making the occurrence of this possible. With the social expectation to always demonstrate mastery of the situation and not appear fearful in the face of the possibility of seeing their lifetime's work undermined, the entrepreneurs seem to absorb the fear of failure in solitude.

One of the characteristics highlighted and researched is that there is little room to admit that fear exists and that it is inherent to the extreme context of starting a business venture (Cardon et. al., 2012). That is, it is up to entrepreneurs to carry the solitary burden of their fear. Elias (1994) indicates some standardization that makes the individuals feel totally alone when they resign and engage in deep secrecy and keep affective control of their true self.

The very success and growth of a business places a burden of responsibility on the entrepreneur for a professional team that it took years to form. Entrepreneurs' fears regarding the succession of their businesses are highlighted in the literature. Schumpeter (1982) already warned of the fact that the pecuniary fruit of an enterprise can be inherited, but the function itself of being an entrepreneur is not inherited. The testimonies also revealed the need for resilience and courage in entrepreneurs, related to instability in the country. This is what the following testimony reveals: "Today we have an extremely unstable and worrying situation. Being a manager of any business today in our country demands constant courage and resilience." (Entrepreneur 3)

The optimism typically attributed to entrepreneurs in general appears in the content of the above statements, expressed in words such as growth, maintaining the organization, courage, and resilience. But by reading between the lines of all the statements it is possible to find the presence of the fear that the entrepreneur feels in relation to the future of their businesses.

\subsection{Specific fears concerning the business sector}

Cardon et al. (2012) and Cacciotti and Hayton (2015) indicate that starting a business venture is an activity that requires high emotional commitment, which can lead to the mistaken impression that fear should not be present in the entrepreneurial journey. The testimonies of the Brazilian entrepreneurs interviewed revealed that fear presents itself in the entrepreneurial journey, intertwined with specific elements of the sectors of their business ventures. Thus, while some fears were shown to be shared by the entrepreneurs interviewed regardless of their areas of activity, others seem to emerge specifically from the particularities of the sector. For instance, entrepreneurs in the private education sector reported that fear of the consequences of defaulting on their business ventures is really present. In Brazil there is an obligation to maintain the service throughout the school year even during non-payment:

\section{The great apprehension that we have as school managers is the country stability issue, because the first bill not to be paid by the families is the school bill, in the case of any financial crisis. And, everyone knows that the school does not have to be lost, because the students do not lose their right by defaulting. We do not have the right to deny the right to study to the student, so for families the first debt acquired is with us, the school. (Entrepreneur 2)}

Another specific fear of the sector is related to how unattractive teaching in schools is for new talents, due to several demotivating factors that occur in Brazil today. The disincentive to the teaching profession is portrayed by one of the entrepreneurs interviewed:

\footnotetext{
"Today we are experiencing a labor
} crisis in schools, the teaching profession 
has been rejected, as professionals in the area are suffering from various nuances that discourage working with schools..." (Entrepreneur 3)

Entrepreneurs in the education sector also presented fear of constant changes in rules without transition periods, which may render the business unfeasible, and the constant and progressive increase in new legal requirements. The fears that emerge from aspects of legislation appear to be based on the variety and complexity of the legislation to which their business ventures are subject:

Many students' rights, many relatives' rights, a lack of discipline not addressed by the families, a great lack of limits, and a legal system that cannot perceive the real value of the teaching profession, concluding numerous times that the student is right and the teacher is wrong. (Entrepreneur 2)

The entrepreneurs' statements revealed specific fears concerning the operating sector. These aspects are confirmed by the research developed by Mota et al (2017), who concluded that economic and human development indicators negatively affect entrepreneurs, contributing to an increase in the fear of failing in their business ventures. This is corroborated by the research from Cacciotti et al. (2016), which indicates that entrepreneurs from the same industry share the same fears, specific not only to the general economic environment, but also to the regulatory changes concerning that sector, and which unfold through fears related to financial aspects.

\subsection{Fears related to financial aspects}

Fear of bankruptcy (Cacciotti \& Hayton, $2015)$ is not the only one connected to financial aspects. What the interviewees said gave rise to different categories in which fears were pertinent to this issue, such as the initial challenge that many had faced as entrepreneurs in finding ways to fund their idea and putting it into practice. But, in the current economic scenario in Brazil, they also report the difficulties and dilemmas involved in managing scarce resources as being a challenge:

It's like this ... it (fear) affects because you have to be projecting your profit, your sales, your margin, you have to be working lean, you have to eliminate everything... avoid wastage, but not only wastage, the investment of new stores, it gets shelved... if you were planning to launch new products, you've already shelved it... if you were planning on credit lines, that too ... because people are also on standby. (Entrepreneur 6)

My greatest fear is that there will be financial instability and that the company will not be able to fulfill its financial commitments - wages, accounts payable (Entrepreneur 2)

The women entrepreneurs interviewed need to perform the role of financial manager in their businesses too, and even without specific training in this area it is up to them to make the best decisions concerning investment, financing, and results for their enterprise, and to also take personal responsibility for the "disaster" arising from any error in these decisions. This responsibility is aggravated, according to the entrepreneurs, by the political and economic context of the country, which greatly increases the burden of company financial management, as the following statements show:

I think all sectors are affected, there is no sector that is not affected, what you have to do is try to be cautious, meet the most varied needs in different publics... The greatest fear of entrepreneurs today is that they cannot get the financial return they expect... their greatest fear is that they cannot keep going financially... (Entrepreneur 6)

It's like dominoes falling. If one falls, they all fall together. (Entrepreneur 4)

Fear is more related to the external context than the fear of facing something, fear of opening the business and the business does not work out. It is a fear that does not exist for us... but at the moment the people 
who would pay are no longer paying ... today we have left our projects on standby. (Entrepreneur 5)

The political and economic instability that the country is experiencing marked the statements of all the interviewees. The current economic and political instability in Brazil is felt by entrepreneurs as if it were "knocking" at the door of their businesses, through the unemployment of their clients, rising taxes, the return of inflation, and the increasing cost of maintaining their businesses. From the statements it was possible to delineate the fears that the women entrepreneurs have in relation to their business ventures due to the crisis, and the way in which they begin to conduct their entrepreneurial activity as a result of these fears:

This is my biggest fear: financial instability. Sales fell by almost fifty percent. So this is the reality that we are facing, we realize that it not only has to do with pleasing the customer, ok we have the customer, right, but it is instability in general, unemployment directly affects the company. (Entrepreneur 4)

We have a project to open another clinic ... but we will not open now because of the current context, because the result of this may be a very big fall for us. If it was like 5, 10 years ago, it would already be opened... so... and we cannot take risks... If I risk opening a new clinic, I can take this one to bankruptcy. So it is one thing, it is a fear, a very great insecurity, even regarding the continuity of this clinic. It is a market much more geared towards putting on a pretty smile than finding a remedy to cure the pain, it is a much more pleasurable thing than pain... only today the market is pain... very symbolic... almost a caricature... (Entrepreneur 5)

As highlighted by Cantillon (2002), entrepreneurs are identified by the risks they are about to take, but it is worth noting that entrepreneurs assess these risks. The interviewees' statements indicate the interaction between fear, entrepreneurial activity, and risk assessment:
"Insecurity is often avoided by new investments and negotiations to improve the quality of business". (Entrepreneur 1)

The testimonies of the entrepreneurial women interviewed contribute to better understanding the solitary fears that accompany the process of starting a business venture, thus breaking what was revealed by Camargo (2016) and Silva (2016), concerning the little that is said about the solitary fear that accompanies this trajectory, placing an extra burden on entrepreneurs. In addition to numerous qualities, success is expected from the entrepreneur, as if described in the script for this role. This role is socially constructed, but the fears experienced in the midst of the context of intense political and economic crises as those experienced by Brazilian entrepreneurs today cannot be ignored.

\section{Final Considerations}

This study was carried out in the midst of an intense political and economic crisis in Brazil, and considers barely discussed aspects concerning entrepreneurial women and their fears in the face of scenarios like this. The entrepreneur's role, regardless of gender, is usually related to attitudes such as risk propensity, fearlessness, boldness, and innovation.

However, it is important to point out that at the same time as entrepreneurs change their environment and the society where they operate, they themselves are altered and affected by it, which leads to them evaluating their role and analyzing the relationship between the risks they are taking and the benefits that may come from their business venture. Thus, the fears concerning what Cardon et al. (2012) calls extreme context, that is, "to start a business venture", are formed through the interaction between entrepreneurs and the business environment or the country where they start their business.

Several fears surfaced during the activity of starting a business venture, as mentioned in the statements of the entrepreneurial women: defaulting and reduced demand for products 
and services, due to their customers being unemployed; increased taxes; the return of inflation; increased costs of maintaining their businesses. These and other fears are sometimes surrounded by loneliness and are expressed in the decisions that accompany the growth of a business venture, and reflect the weight of feeling responsible for maintaining a business that offers work, possibilities, and opportunities to various employees.

Using the results of this study, new investigations can be carried out that address the issue of the fear that emerges in men and women when engaging in entrepreneurial activity, thus expanding the investigation beyond fear of bankruptcy or fear of opening a new business. New research could, for example, aim to investigate how the fear that emerges in the extreme context of opening a new business is presented in the constitution of the identity of the people who experience the entrepreneurial activity.

To conclude, it is possible to reflect, after hearing the entrepreneurs' statements, that fear can be in constant contradiction: present and hidden. It is a burden that the entrepreneur carries alone and is not able to share with her employees, partner, or relatives. So, it remains there, throbbing like a lonely pain..., but also as a warning about the present... and a hope for the future. In this sense it is in itself contradictory and ambiguous.

\section{References}

Anokhin, S., \& Abarca, K. M. (2011). Entrepreneurial opportunities and the filtering role of human agency: Resolving the objective-subjective-realized conundrum (summary). Frontiers of Entrepreneurship Research, 31(15), Article 4, 499-500.

Arroyo, M. R., Fuentes, M. D. M. F., \& Jiménez, J. M. R. (2016). Um estudo internacional sobre os fatores que explicam a expectativa de alto crescimento em novos empreendimentos: Uma perspectiva de gênero. Revista Brasileira de Gestâo de Negócios, 18(60), 171-190.

Becker, Howard. (1999). Métodos de pesquisa em ciências sociais. São Paulo: Hucitec.

(2007). Segredos e Truques

da Pesquisa. Rio de Janeiro: Zahar.

Bosma, N., \& Schutjens, V. (2011). Understanding regional variation in entrepreneurial activity and entrepreneurial attitude in Europe. The Annals of Regional Science, 47(3), 711-742.

Cacciotti, G., \& Hayton, J. C. (2015). Fear and entrepreneurship: A review and research agenda. International Journal of Management Reviews, 17(2), 165-190.

Cacciotti, G., Hayton, J. C., Mitchell, J. R., \& Giazitzoglu, A. (2016). A reconceptualization of fear of failure in entrepreneurship. Journal of Business Venturing, 31(3), 302-325.

Camargo, R. A. M. M. D. (2016). A constituição da identidade do empreendedor em educação sob a perspectiva do interacionismo simbólico (Master's dissertation). Universidade Federal do Paraná, Curitiba, PR, Brazil.

Cantillon, R. (2002). Ensaio sobre a natureza do comércio em geral. Curitiba: Segesta Editora.

Cardon, M. S., Foo, M. D., Shepherd, D., \& Wiklund, J. (2012). Exploring the heart: Entrepreneurial emotion is a hot topic. Entrepreneurship Theory and Practice, 36(1), 1-10.

Creswell, J. W. (2010). Projeto de pesquisa: Métodos qualitativo, quantitativo e misto (3a ed.). Porto Alegre: Bookman.

Elias, N. (1994). A sociedade dos individuos. Rio de Janeiro: Jorge Zahar.

Ferreira, J. M., \& Nogueira, E. E. S. (2013). Mulheres e suas histórias: Razão, sensibilidade e subjetividade no empreendedorismo 
feminino. Revista de Administração Contemporânea, 17(4), 398-417.

Folha de São Paulo. (2016, março 21). Mercado prevê inflação de 7,43\% e amplia queda do PIB a $3,6 \%$ neste ano. Available from < http://www1. folha.uol.com.br/mercado/2016/03/1752252mercado-preve-inflacao-de-743-e-amplia-quedado-pib-a-36-neste-ano.shtml $>$ Accessed on $11 / 25 / 2017$.

Fraga, E. (March 2016). Estudo indica que atraso econômico do Brasil aumenta riscos de protestos. Folha de São Paulo. Available from< http://www1. folha.uol.com.br/mercado/2016/03/1752117estudo-indica-que-atraso-economico-do-brasilaumenta-risco-de-protestos.shtml > Accessed on $11 / 25 / 2017$.

Gimenez, F. A. P. (2013). Empreendedorismo e pequena empresa: Dezesseis Haikais, um pouco de prosa e outros versos. Curitiba: From the Author.

Gimenez, F. A. P., Ferreira, J. M., \& Ramos, S. C. (2017). Empreendedorismo feminino no Brasil: Gênese e formação de um campo de pesquisa. Revista de Empreendedorismo e Gestão de Pequenas Empresas, 6(1), 40-74.

Global Entrepreneurship Monitor (2015). Empreendedorismo no Brasil 2015: Relatório Executivo. Curitiba: IBQP. Retrieved from: http://www.bibliotecas.sebrae.com.br/chronus/ ARQUIVOS CHRONUS/bds/bds.nsf/c6de90 7fe0574c8ccb36328e24b2412e/\$File/5904.pdf

Godoi, C. K., Bandeira-de-Mello, R., \& Silva, A. D. (2010). Pesquisa qualitativa em estudos organizacionais: paradigmas, estratégias e métodos. ( $2^{\text {nd }}$ ed.). São Paulo: Saraiva.

Godoy, A. S. (2005). Refletindo sobre critérios de qualidade da pesquisa qualitativa. Revista Eletrônica de Gestão Organizacional,3(1), 8089. Recuperado de http://www.spell.org.br/ documentos/ver/11383/refletindo-sobre-criteriosde-qualidade-da-pesquisa-qualitativa/i/pt-br
Goffman, E. (2014). A representação do eu na vida cotidiana (20 ${ }^{\text {th }}$ ed.). São Paulo: Perspectiva.

Goffman, E. (2015). Manicômios, prisóes e conventos ( $9^{\text {th }}$ ed.). São Paulo: Perspectiva.

Gomes, A. F., Santana, W. G. P., Araújo, U. P., \& Martins, C. M. F. (2014). Empreendedorismo feminino como sujeito de pesquisa. Revista Brasileira de Gestão de Negócios, 16(51), 319-342.

Hessels, J., Grilo, I., Thurik, R., \& Zwan, P. Van der (2011). Entrepreneurial exit and entrepreneurial engagement. Journal of Evolutionary Economics, 21(3), 447-471.

Khefacha, I., Belkacem, L., \& Mansouri, F. (2013). The decision to start a new firm: An econometric analysis of regional entrepreneurship in Tunisia. IBIMA Business Review, 2013,1-12.

Koellinger, P., Minniti, M., \& Schade, C. (2013). Gender differences in entrepreneurial propensity. Oxford bulletin of economics and statistics, 75(2), 213-234.

Machado, H. V., Greatti, L., \& de Jesus, M. J. (2010). Compreendendo a imersão de empreendedoras em redes: A institucionalização da Associação de Mulheres de Negócios de Maringá. In F. Gimenez, J. M. Ferreira, S. C. Ramos (Eds.), Empreendedorismo e Estratégia de Empresas de Pequeno Porte 3Es2Ps (Coleção Empreendedorismo e Estratégia, 1, pp. 85104). Curitiba: Champagnat. Retrieved from http://www.editorachampagnat.pucpr.br/ ebook/9788572922043.pdf\#page $=87$

McClelland, D. C. (1971). The achievement motive in economic growth. In P. Kilby (Ed.), Entrepreneurship and economic development (pp. 109-122). New York: The Free Press.

McClelland, D. C. (1987). Human motivation. Cambridge University Press. 
Merriam, S. B. (1998). Qualitative Research and Case Study Applications in Education. Revised and Expanded from" Case Study Research in Education.". Jossey-Bass Publishers, 350 Sansome St, San Francisco.

(2002). Qualitative research in practice: Examples for discussion and analysis. Jossey-Bass Inc Pub.

(2009). Qualitative Research: A guide to design and implementation: Revised and expanded from qualitative research and case study applications in education. Jossey-Bass Publishers, 350 Sansome St, San Francisco.

Minniti, M., \& Nardone, C. (2007). Being in someone else's shoes: The role of gender in nascent entrepreneurship. Small Business Economics, 28(2), 223-238.

Morgan, J., \& Sisak, D. (2016). Aspiring to succeed: A model of entrepreneurship and fear of failure. Journal of Business Venturing, 31(1), 1-21.

Mota, M. O., Sobreira, M. C., Vale, M. S., \& Nogueira, L. C. C. (2017). Relações de influência de indicadores macroeconômicos na propensão ao risco de empreender. REGE-Revista de Gestão, 24(2), 159-169.

Noguera, M., Alvarez, C., \& Urbano, D. (2013). Socio-cultural factors and female entrepreneurship. International Entrepreneurship and Management Journal, 9(2), 183-197.

Pagès, M., Bonetti, M., Gaulejac, V., \& Descendre, D. (1987). O poder das organizaçôes. São Paulo: Atlas.

Patu, G., \& Bôas, B. V. (2016, março 04). Brasil enfrenta a recessão mais profunda em 20 anos. Folha de São, Mercado. Retrieved from http://www1. folha.uol.com.br/mercado/2016/03/1746161brasil-enfrenta-a-recessao-mais-profunda-em-20anos.shtml

Qian, S., \& Miao, C. (2016). How perception, knowledge, and cultural values influence entrepreneurs'fear: a multi-level investigation. Academy of Entrepreneurship Journal, 22(2), 29-38.

Ramos, S. C. (2015). Macrocognição no processo decisório de empreendedores experts (Doctoral thesis). Universidade Federal do Paraná, Curitiba, PR, Brazil.

Santos, L. O. (2003). O Medo contemporâneo: Abordando suas diferentes dimensôes. Psicologia Ciência e Profissão. 23(2), 48-55.

Schumpeter, J. (1982). A. Teoria do desenvolvimento econômico: Uma investigação sobre lucros, capital, crédito, juro e o ciclo econômico. São Paulo: Abril Cultural.

Silva, J. A. (2016). O papel do empreendedor apresentado pela mídia especializada de negócios (Master's dissertation). Universidade Federal do Paraná, Curitiba, PR, Brazil.

Strauss, A. L. (1999). Espelhos e máscaras. São Paulo: Edusp.

Strauss, A. L., \& Corbin, J. (2008). Pesquisa qualitativa: Técnicas e procedimentos para o desenvolvimento de teoria fundamentada ( $2^{\text {nd }} \mathrm{ed}$.). Porto Alegre: Artmed.

Wagner, J. (2007). What a difference a Y makesfemale and male nascent entrepreneurs in Germany. Small Business Economics, 28(1), 1-21.

Welpe, I. M., Sporrle, M., Grichnik, D., $\&$ Audretsch, D. (2012). Emotions and opportunities: The interplay of opportunity evaluation, fear, joy, and anger as antecedent of entrepreneurial exploration. Entrepreneurship Theory and Practice, 36(1), 69-96.

Wood, M. S., \& Pearson, J. M. (2009). Taken on faith? The impact of uncertainty, knowledge relatedness, and richness of information on entrepreneurial opportunity exploitation. Journal of Leadership \& Organizational Studies, 16(2), 117-130. 


\section{Supporting Agencies:}

CAPES - Coordenação de Aperfeiçoamento de Pessoal de Nível Superior

About the Authors:

1. Raquel Adriano Momm Maciel de Camargo, MSc in Management, Federal University of Parana, Brazil. E-mail:raquelmomm@gmail.com

ORCID

(iD) 0000-0001-5858-3390

2. Mariane Lemos Lourenço, PhD in Psychology, University of São Paulo, São Paulo, Brazil. E-mail: psimari@uol.com.br

ORCID

0000-0003-2887-9232

3. Jane Mendes Ferreira, PhD in Management, Positivo University, Curitiba, Brazil. E-mail: janemendesff@ yahoo.com.br

ORCID

(iD) 0000-0001-6299-6964

\section{Contribution of each author:}

\begin{tabular}{|c|c|c|c|}
\hline Contribution & $\begin{array}{l}\text { Raquel Adriano } \\
\text { Momm Maciel de } \\
\text { Camargo }\end{array}$ & $\begin{array}{l}\text { Mariane Lemos } \\
\text { Lourenço }\end{array}$ & $\begin{array}{l}\text { Jane Mendes } \\
\text { Ferreira }\end{array}$ \\
\hline 1. Definition of research problem & $\sqrt{ }$ & $\sqrt{ }$ & $\sqrt{ }$ \\
\hline $\begin{array}{l}\text { 2. Development of hypotheses or research questions (empirical } \\
\text { studies) }\end{array}$ & $\sqrt{ }$ & $\sqrt{ }$ & $\sqrt{ }$ \\
\hline 3. Development of theoretical propositions (theoretical Work) & $\sqrt{ }$ & $\sqrt{ }$ & $\sqrt{ }$ \\
\hline 4. Theoretical foundation/ Literature review & $\sqrt{ }$ & $\sqrt{ }$ & $\sqrt{ }$ \\
\hline 5. Definition of methodological procedures & $\sqrt{ }$ & $\sqrt{ }$ & $\sqrt{ }$ \\
\hline 6. Data collection & $\sqrt{ }$ & $\sqrt{ }$ & $\sqrt{ }$ \\
\hline 7. Statistical analysis & $\sqrt{ }$ & $\sqrt{ }$ & $\sqrt{ }$ \\
\hline 8. Analysis and interpretation of data & $\sqrt{ }$ & $\sqrt{ }$ & $\sqrt{ }$ \\
\hline 9. Critical revision of the manuscript & $\sqrt{ }$ & $\sqrt{ }$ & $\sqrt{ }$ \\
\hline 10. Manuscript Writing & $\sqrt{ }$ & $\sqrt{ }$ & $\sqrt{ }$ \\
\hline
\end{tabular}

